\title{
Synthesis of novel antimitotic agents based on 2-amino-3-aroyl-5-(hetero)arylethynyl thiophene derivatives
}

\author{
Romeo Romagnoli ${ }^{\mathrm{a}, *}$, Pier Giovanni Baraldi ${ }^{\mathrm{a}, *}$, Olga Cruz-Lopez ${ }^{\mathrm{a}}$, Manlio Tolomeo ${ }^{\mathrm{b}}$, Antonietta Di Cristina ${ }^{\mathrm{b}}$, \\ Rosaria Maria Pipitone $^{\mathrm{b}}$, Stefania Grimaudo ${ }^{\mathrm{b}}$, Jan Balzarini ${ }^{\mathrm{c}}$, Andrea Brancale ${ }^{\mathrm{d}}$, Ernest Hamel ${ }^{\mathrm{e}}$ \\ a Dipartimento di Scienze Farmaceutiche, Università di Ferrara, 44100 Ferrara, Italy \\ ${ }^{\mathrm{b}}$ Centro Interdipartimentale di Ricerca in Oncologia Clinica e Dipartimento Biomedico di Medicina Interna e Specialistica, Università di Palermo, Palermo, Italy \\ ${ }^{\mathrm{c}}$ Rega Institute for Medical Research, Laboratory of Virology and Chemotherapy, Minderbroedersstraat 10, B-3000 Leuven, Belgium \\ ${ }^{\mathrm{d}}$ The Welsh School of Pharmacy, Cardiff University, King Edward VII Avenue, Cardiff CF10 3XF, UK \\ e Screening Technologies Branch, Developmental Therapeutics Program, Division of Cancer Treatment and Diagnosis, National Cancer Institute at Frederick, \\ National Institutes of Health, Frederick, MD 21702, USA
}

\section{A R T I C L E I N F O}

\section{Article history:}

Received 15 October 2010

Revised 9 November 2010

Accepted 16 November 2010

Available online 21 November 2010

\section{Keywords:}

Thiophene

Inhibition of tubulin polymerization

Inhibition of tumor cell growth

Antiproliferative agents

\begin{abstract}
A B S T R A C T
Microtubules are dynamic structures that play a crucial role in cellular division and are recognized as an important target for cancer therapy. In search of new compounds with strong antiproliferative activity and simple molecular structure, a new series of 2-amino-3-(3',4',5'-trimethoxybenzoyl)-5-(hetero)aryl ethynyl thiophene derivatives was prepared by the Sonogashira coupling reaction of the corresponding 5-bromothiophenes with several (hetero)aryl acetylenes. When these compounds were analyzed in vitro for their inhibition of cell proliferation, the 2- and 3-thiophenyl acetylene derivatives were the most powerful compounds, both of which exerted cytostatic effects at submicromolar concentrations. In contrast, the presence of a more flexible ethyl chain between the (hetero)aryl and the 5-position of the thiophene ring resulted in significant reduction in activity relative to the 5-(hetero)aryl acetylene substituted derivatives. The effects of a selected series of compounds on cell cycle progression correlated well with their strong antiproliferative activity and inhibition of tubulin polymerization. We found that the antiproliferative effects of the most active compounds were associated with increase of the proportion of cells in the $G_{2} / M$ and sub- $G_{1}$ phases of the cell cycle.
\end{abstract}

(c) 2010 Elsevier Ltd. All rights reserved.
The microtubule system of eukaryotic cells is essential in a variety of fundamental cellular processes, including mitosis, formation and maintenance of cell shape, regulation of motility, cell signaling, secretion, and intracellular transport. ${ }^{1,2}$ There has long been considerable interest in the discovery and development of novel small molecules, many of which are natural products, able to inhibit tubulin polymerization for the treatment of cancer. ${ }^{3-5}$ Combretastatin A-4 (CA-4, 1), isolated from an African willow, Combretum caffrum (Combretaceae), shows interesting anticancer potential due to its antitubulin properties. ${ }^{6}$ Previous studies have found that the $3^{\prime}, 4^{\prime}, 5^{\prime}$-trimethoxy group on the A ring was essential for strong activity, while the $3^{\prime}$-hydroxy group on the B-ring is not necessary for potent activity. ${ }^{7-9}$ CA-4 strongly binds to the colchicine site of tubulin, and this binding prevents tubulin polymerization and causes an antimitotic effect. CA- 4 inhibits cell growth at low to mid nanomolar concentrations, and its structural

\footnotetext{
* Corresponding authors. Tel.: +39(0)532 455303; fax: +39(0)532 455953 (R.R.); tel.: 39(0)532 291293; fax: +39(0)532 455953 (P.G.B.).
}

E-mail addresses: rmr@unife.it (R. Romagnoli), baraldi@unife.it (P.G. Baraldi). simplicity makes CA-4 of great interest from the medicinal chemistry viewpoint. ${ }^{10}$

For these reasons, a large number of synthetic CA- 4 analogues have been synthesized and evaluated in structure-activity relationship (SAR) studies. ${ }^{7-12}$ Replacing the double bound of CA-4 with a carbonyl group furnished a benzophenone-type CA-4 analogue named phenstatin (2), which was found to be a very strong cytotoxic agent with the same characteristics as CA-4. ${ }^{13}$ The 2-aminobenzophenone derivative $\mathbf{3}$ showed significantly increased cytotoxicity against many human cancer cell lines as compared with phenstatin $\mathbf{2}$, but 3 was nevertheless slightly less potent than CA-4. ${ }^{14}$

The classical bioisosteric equivalence between benzene and thiophene prompted us to synthesize a series of 2-amino-3$\left(3^{\prime}, 4^{\prime}, 5^{\prime}\right.$-trimethoxybenzoyl)thiophene derivatives with general formula 4 , in which a 2-aminothiophene system replaced the 2-aminobenzene moiety in the 2-aminophenstatin analogue $3 .^{15}$ The 4,5-unsubstituted derivative 4 a displayed modest activity, which was little affected with alkyl or halogen substituents at C-5. The weak activity of $\mathbf{4 a}$ was enhanced up to 12 -fold by the 4-methyl substitution (compound $\mathbf{4 b}$ ). The contribution of the phenyl group to activity was position dependent. Placing a phenyl 
at $\mathrm{C}-4(\mathbf{4 c})$ resulted in an inactive compound, while the corresponding C-5 phenyl derivative $4 d$ was a potent inhibitor of tubulin polymerization and showed strong antiproliferative activities against two leukemic cell lines, L1210 and K562, with accumulation of cells in the $G_{2} / M$ phase of the cell cycle.

On the basis of previous encouraging results on the antitumor activity of compound 4d, we have now extended this study by the synthesis and biological evaluation of a related series of compounds with general structure $\mathbf{5}$, characterized by a common 2-amino-3-(3', 4',5'-trimethoxybenzoyl)-thiophene core but with an aryl/heteroaryl ethynedyl moiety at the C-5-position of the thiophene ring. The substituents examined at the 4-position included hydrogen or methyl. Partial or complete reduction of ethynyllinked compounds $\mathbf{5 a - h}$ afforded vinyl- and ethyl-linked derivatives $\mathbf{5 i}-\mathbf{j}$ and $\mathbf{5 k} \mathbf{k}-\mathbf{o}$, respectively. By the preparation of compounds 5c, 5d, 5m and 5n, we explored the SAR by examining electronreleasing ( $\mathrm{Me}$ and $\mathrm{MeO}$ ) groups on the $p$-position of the phenyl of phenyethynyl or phenylethyl moieties (compounds $\mathbf{5 c}$, $\mathbf{5 d}$, and $\mathbf{5 m}, \mathbf{5 n}$, respectively) (Chart 1 ).

The 3',4',5'-trimethoxyphenyl of the 2-benzoyl moiety was kept unchanged because it is the characteristic structural requirement for activity in a large series of inhibitors of tubulin polymerization, such as colchicine, combretastatin A-4, and podophyllotoxin. ${ }^{7,16}$

The approach taken for the preparation of compounds $\mathbf{5 a - o}$ is shown in Scheme 1 . The treatment of the 2,5-dimethyl-(1,4)dithiane-2,5-diol (the dimer of $\alpha$-mercaptoacetone) or 1,4-dithiane-2,
5 -diol (the dimer of $\alpha$-mercaptoacetaldehyde) in ethanol with triethylamine (TEA) (2.2 equiv) followed by the addition of 3-(3',4',5'-trimethoxyphenyl)-3-oxopropanenitrile $6,{ }^{15}$ furnished

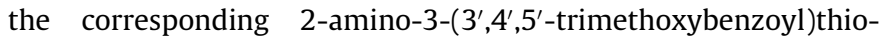
phenes $\mathbf{7 a}$ or $\mathbf{7 b}$, respectively. These latter compounds were converted almost quantitatively to the phthalimido derivatives 8a and $\mathbf{8 b}$ using phthalic anhydride in acetic acid, and the subsequent regioselective bromination of $\mathbf{8 a}$ and $\mathbf{8 b}$ in a mixture of acetic acid and sodium acetate using bromine, furnished intermediates 5-bromothiophene derivatives $\mathbf{9 a}$ and $\mathbf{9 b}$. These latter compounds were coupled by a standard Sonogashira cross-coupling reaction ${ }^{17}$ with the appropriate alkyne in the presence of cuprous iodide (CuI), bis(triphenylphosphine)-palladium chloride $\left[\mathrm{PdCl}_{2}\left(\mathrm{PPh}_{3}\right)_{2}\right]$ and a mixture of TEA and DMF, to afford the (hetero)arylacetylenic derivatives 10a-h. The removal of the $\mathrm{N}$-protected phthaloyl group was accomplished by the use of hydrazine in refluxing ethanol, to afford compounds $\mathbf{5 a}-\mathbf{h}$. Partial hydrogenation of the triple $\mathrm{C}-\mathrm{C}$ bonds of $\mathbf{5 e}$ and $\mathbf{5 g}$ with Lindlar's catalyst (5\% palladium on calcium carbonate poisoned with lead) gave $\mathbf{5 i}$ and $\mathbf{5 j}$, respectively, as $(Z)$-isomers in acceptable yields. Compounds $\mathbf{5 k} \mathbf{k}-\mathbf{o}$, characterized by the presence of a more flexible ethyl linker, were prepared starting from derivatives $\mathbf{5 a - d}$ and $\mathbf{5 g}$, respectively, by catalytic hydrogenation of the triple bond over $10 \%$ palladium on charcoal $(\mathrm{Pd} / \mathrm{C})$.

Table 1 summarizes the growth inhibitory effects of derivatives 5a-o against murine leukemia (L1210), human cervix carcinoma<smiles>COc1ccc(/C=C\c2cc(OC)c(OC)c(OC)c2)cc1O</smiles>

Combretastatin A-4 (CA-4), 1<smiles>[R]CCc1sc(N)c(C(=O)c2cc(OC)c(OC)c(OC)c2)c1[R]</smiles>

$\mathrm{R}^{1}=\mathrm{H}, \mathrm{R}^{2}=\mathrm{C}_{6} \mathrm{H}_{5}, \mathbf{5 k}$

$\mathrm{R}^{1}=\mathrm{CH}_{3}, \mathrm{R}^{2}=\mathrm{C}_{6} \mathrm{H}_{5}, 5 \mathrm{I}$

$\mathrm{R}^{1}=\mathrm{H}, \mathrm{R}^{2}=p-\mathrm{Me}-\mathrm{C}_{6} \mathrm{H}_{4}, 5 \mathrm{~m}$

$\mathrm{R}^{1}=\mathrm{H}, \mathrm{R}^{2}=p-\mathrm{OMe}-\mathrm{C}_{6} \mathrm{H}_{4}, \mathbf{5 n}$

$\mathrm{R}^{1}=\mathrm{H}, \mathrm{R}^{2}=$ thiophen-3-yl, 5o<smiles>[R]c1ccc(C(=O)c2cc(O)c(OC)c(OC)c2)c([R])c1[R]</smiles>

$\mathrm{R}^{1}=\mathrm{H}, \mathrm{R}^{2}=\mathrm{OH}, \mathrm{R}^{3}=\mathrm{OCH}_{3}$, Phenstatin, 2

$\mathrm{R}^{1}=\mathrm{NH}_{2}, \mathrm{R}^{2}=\mathrm{H}, \mathrm{R}^{3}=\mathrm{OCH}_{3}, 3$<smiles>[R]C#Cc1sc(N)c(C(=O)c2cc(OC)c(OC)c(OC)c2)c1[R]</smiles>

$\mathrm{R}^{1}=\mathrm{H}, \mathrm{R}^{2}=\mathrm{C}_{6} \mathrm{H}_{5}, \mathbf{5 a}$

$\mathrm{R}^{1}=\mathrm{CH}_{3}, \mathrm{R}^{2}=\mathrm{C}_{6} \mathrm{H}_{5}, \mathbf{5 b}$

$\mathrm{R}^{1}=\mathrm{H}, \mathrm{R}^{2}=p-\mathrm{Me}-\mathrm{C}_{6} \mathrm{H}_{4}, \mathbf{5 c}$

$\mathrm{R}^{1}=\mathrm{H}, \mathrm{R}^{2}=p-\mathrm{OMe}-\mathrm{C}_{6} \mathrm{H}_{4}, \mathbf{5 d}$

$\mathrm{R}^{1}=\mathrm{H}, \mathrm{R}^{2}=$ thiophen-2-yl, 5e

$\mathrm{R}^{1}=\mathrm{Me}, \mathrm{R}^{2}=$ thiophen-2-yl, $\mathbf{5 f}$

$\mathrm{R}^{1}=\mathrm{H}, \mathrm{R}^{2}=$ thiophen-3-yl, $\mathbf{5 g}$

$\mathrm{R}^{1}=\mathrm{Me}, \mathrm{R}^{2}=$ thiophen-3-yl, $\mathbf{5 h}$<smiles>[R]C=Cc1cc(C(=O)c2cc(OC)c(OC)c(OC)c2)c(N)s1</smiles>

$\mathrm{R}=$ thiophen-2-yl, $\mathbf{5 i}$

$\mathrm{R}=$ thiophen-3-yl, 5j

Chart 1. 
<smiles>COc1cc(C(=O)CC#N)cc(OC)c1OC</smiles>

$$
\begin{aligned}
& \mathrm{R}^{1}=\mathrm{H}, \mathrm{R}^{2}=\mathrm{C}_{6} \mathrm{H}_{5}, \mathbf{5 k} \\
& \mathrm{R}^{1}=\mathrm{CH}_{3}, \mathrm{R}^{2}=\mathrm{C}_{6} \mathrm{H}_{5}, \mathbf{5 l} \\
& \mathrm{R}^{1}=\mathrm{H}, \mathrm{R}^{2}=\mathrm{p}-\mathrm{Me}-\mathrm{C}_{6} \mathrm{H}_{4}, 5 \mathrm{~m} \\
& \mathrm{R}^{1}=\mathrm{H}, \mathrm{R}^{2}=\mathrm{p}-\mathrm{OMe}-\mathrm{C}_{6} \mathrm{H}_{4}, \mathbf{5 n} \\
& \mathrm{R}^{1}=\mathrm{H}, \mathrm{R}^{2}=\text { thiophen-3-yl, 5o }
\end{aligned}
$$<smiles>[R]C=Cc1cc(C(=O)c2cc(OC)c(OC)c(OC)c2)c(N)s1</smiles>

$\mathrm{R}=$ thiophen $-2-\mathrm{yl}, \mathbf{5 i}$ $\mathrm{R}=$ thiophen-3-yl, $5 \mathbf{j}$<smiles>[R]c1csc(N)c1C(=O)c1cc(OC)c(OC)c(OC)c1</smiles>

$\mathrm{R}^{1}=\mathrm{H}, 7 \mathrm{a}$

$\mathrm{R}^{1}=\mathrm{Me}, \mathbf{7 b}$

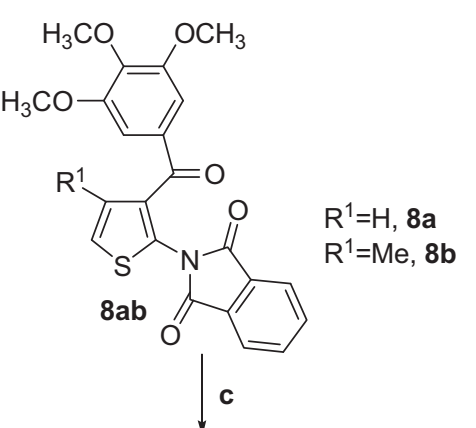<smiles>COc1cccc(OC)c1OC</smiles>

$\mathrm{R}^{1}=\mathrm{H}, 9 \mathrm{a}$

$\mathrm{R}^{1}=\mathrm{Me}, \mathbf{9 b}$<smiles>[R]CCc1sc(N)c(C(=O)c2cc(OC)c(OC)c(OC)c2)c1[R]</smiles>

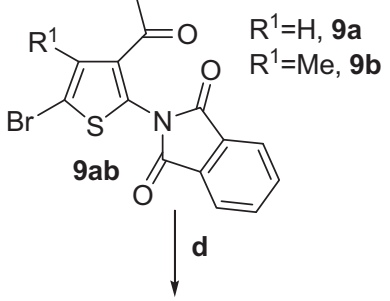<smiles>[R]C#Cc1sc(N2C(=O)c3ccccc3C2=O)c(C(=O)c2cc(OC)c(OC)c(OC)c2)c1[R]</smiles>

$\mathrm{R}^{1}=\mathrm{H}, \mathrm{R}^{2}=\mathrm{C}_{6} \mathrm{H}_{5}, 10 \mathrm{a}, 5 \mathrm{a}$

$\mathrm{R}^{1}=\mathrm{CH}_{3}, \mathrm{R}^{2}=\mathrm{C}_{6} \mathrm{H}_{5}, \mathbf{1 0 b}, \mathbf{5 b}$

$\mathrm{R}^{1}=\mathrm{H}, \mathrm{R}^{2}=\mathrm{p}-\mathrm{Me}-\mathrm{C}_{6} \mathrm{H}_{4}, \mathbf{1 0 b}, \mathbf{5 c}$

$\mathrm{R}^{1}=\mathrm{H}, \mathrm{R}^{2}=\mathrm{p}-\mathrm{OMe}-\mathrm{C}_{6} \mathrm{H}_{4}, \mathbf{1 0 d}, \mathbf{5 d}$

$\mathrm{R}^{1}=\mathrm{H}, \mathrm{R}^{2}=$ thiophen-2-yl, 10e, 5e

$R^{1}=M e, R^{2}=$ thiophen-2-yl, 10f, $\mathbf{5 f}$

$\mathrm{R}^{1}=\mathrm{H}, \mathrm{R}^{2}=$ thiophen-3-yl, $\mathbf{1 0 g}, \mathbf{5 g}$

$\mathrm{R}^{1}=\mathrm{Me}, \mathrm{R}^{2}=$ thiophen-3-yl, 10h, 5h

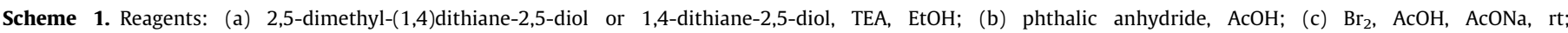

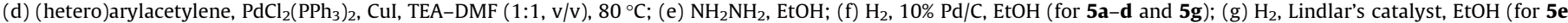
and 5g).

(HeLa), murine mammary carcinoma (FM3A) and human T-lymphoblastoid (Molt/4 and CEM) cells. The alkylating agent melphalan and compounds 4de were used as reference drugs. 2Amino-3-(3',4',5'-trimethoxybenzoyl)-5-(thiophen-3'-yl ethynyl) thiophene $\mathbf{5 g}$ possessed the highest potency and inhibited the growth of L1210, FM3A, Molt/4, CEM, and HeLa cancer cell lines with $\mathrm{IC}_{50}$ 's of $0.21,0.13,0.096,0.11$, and $0.20 \mu \mathrm{M}$, respectively. The antiproliferative potency of 5 a was diminished relative to compound $4 \mathbf{d}$ with the phenyl directly bounded at the $C 5$ position of the 2-amino3-(3',4',5'-trimethoxybenzoyl)-thiophene core. Derivatives 5ab and $\mathbf{5 e - j}$ were found to be significantly more active than melphalan against the tested cancer cell lines. The presence of an ethynyl (compounds $\mathbf{5 a}-\mathbf{h}$ ) or ethenyl (compounds $\mathbf{5 i}$ and $\mathbf{5 j}$ ) group at the 5-position of 2-amino-3-(3',4',5'-trimethoxybenzoyl)thiophene is essential for activity, sice congeners with an ethyl group at that position (compounds $\mathbf{5 k}$ and $\mathbf{5 m - 0}$ ) were generally inactive.

While the unsubstituted phenylacetylene derivative $\mathbf{5 a}$ exerted antiproliferative activity at low micromolar concentrations, the introduction of an electron-releasing methyl or methoxy group at the para-position of the phenylethynyl unit (analogues $\mathbf{5 c}$ and $\mathbf{5 d}$, respectively) caused substantial loss of activity $\left(\mathrm{IC}_{50}>10 \mu \mathrm{M}\right)$. The introduction of a methyl group in the 4-position of the 2-amino-3-( $3^{\prime}, 4^{\prime}, 5^{\prime}$-trimethoxybenzoyl)-thiophene skeleton (compound $\mathbf{5 b}$ ) led to no change in activity, relative to $\mathbf{5 a}$, against the tumor cells.

The bioisosteric replacement of phenyl in $\mathbf{5 a}$ by a thiophene, in either regioisomeric orientation, to furnish the $2^{\prime}$ - and $3^{\prime}$-thiophenyl derivatives $5 \mathbf{e}$ and $\mathbf{5 g}$, have a beneficial effect on antiproliferative activity. In contrast to the situation with thiophen-2'-ylacetylene derivatives $\mathbf{5 e}$ and $\mathbf{5 f}$, where the introduction of methyl group in the 4-position of the 2-amino-3-(3',4',5'-trimethoxybenzoyl)-thiophene skeleton (compound $\mathbf{5 f}$ ) led to little change in activity, with the isomeric thiophen-3'-ylacetylene derivative $\mathbf{5 g}$ the 4-methyl group (compound $\mathbf{5 h}$ ) was not well-tolerated and caused a two to fourfold reduction in activity against L1210, FM3A, Molt4, and CEM cells, but no effect on activity against HeLa cells. 
Table 1

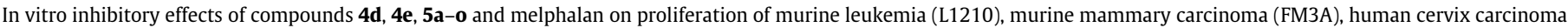
(HeLa) and human T-lymphocyte (Molt/4 and CEM) cells

\begin{tabular}{|c|c|c|c|c|c|}
\hline \multirow[t]{2}{*}{ Compound } & \multicolumn{5}{|c|}{$\mathrm{IC}_{50} \pm \mathrm{S} . \mathrm{D}(\mu \mathrm{M})^{\mathrm{a}}$} \\
\hline & L1210 & FM3A/0 & Molt4/C8 & CEM/0 & HeLa \\
\hline $5 a$ & $2.6 \pm 0.1$ & $2.5 \pm 0.1$ & $1.5 \pm 0.4$ & $1.9 \pm 0.0$ & $1.6 \pm 0.7$ \\
\hline $5 \mathbf{b}$ & $3.0 \pm 0.6$ & $3.3 \pm 0.9$ & $2.1 \pm 0.0$ & $2.1 \pm 0.1$ & $1.6 \pm 0.6$ \\
\hline $5 c$ & $>10$ & $>10$ & $>10$ & $>10$ & $>10$ \\
\hline $5 d$ & $>10$ & $>10$ & $>10$ & $>10$ & $>10$ \\
\hline $5 e$ & $0.52 \pm 0.01$ & $0.42 \pm 0.01$ & $0.42 \pm 0.06$ & $0.46 \pm 0.04$ & $0.20 \pm 0.02$ \\
\hline $5 f$ & $0.52 \pm 0.03$ & $0.46 \pm 0.00$ & $0.47 \pm 0.06$ & $0.53 \pm 0.00$ & $0.18 \pm 0.01$ \\
\hline $5 g$ & $0.21 \pm 0.04$ & $0.13 \pm 0.00$ & $0.096 \pm 0.012$ & $0.11 \pm 0.01$ & $0.20 \pm 0.12$ \\
\hline $5 h$ & $0.45 \pm 0.01$ & $0.33 \pm 0.04$ & $0.45 \pm 0.03$ & $0.48 \pm 0.00$ & $0.12 \pm 0.04$ \\
\hline $5 \mathbf{i}$ & $0.16 \pm 0.13$ & $0.41 \pm 0.39$ & $0.13 \pm 0.20$ & $0.56 \pm 0.61$ & $0.16 \pm 0.01$ \\
\hline $5 \mathbf{j}$ & $2.3 \pm 0.0$ & $0.41 \pm 0.01$ & $0.63 \pm 0.21$ & $1.3 \pm 1.1$ & $1.3 \pm 0.7$ \\
\hline $5 k$ & $>10$ & $11 \pm 2$ & $6.6 \pm 1.6$ & $8.7 \pm 0.0$ & $7.3 \pm 3.0$ \\
\hline 51 & $>10$ & $>10$ & $>10$ & $>10$ & $>10$ \\
\hline $5 \mathrm{~m}$ & $>10$ & $>10$ & $>10$ & $>10$ & $>10$ \\
\hline $5 n$ & $>10$ & $>10$ & $>10$ & $>10$ & $>10$ \\
\hline 50 & $5.0 \pm 3.3$ & $5.2 \pm 4.0$ & $1.9 \pm 0.4$ & $2.1 \pm 0.2$ & $7.6 \pm 0.2$ \\
\hline 4d & $0.012 \pm 0.00$ & $0.0096 \pm 0.00$ & $0.0030 \pm 0.00$ & $0.0029 \pm 0.00$ & $0.012 \pm 0.00$ \\
\hline $4 e$ & $1.3 \pm 1.1$ & $1.6 \pm 0.6$ & $0.31 \pm 0.09$ & $0.16 \pm 0.02$ & $0.85 \pm 0.44$ \\
\hline Melphalan & $8.6 \pm 0.3$ & $3.6 \pm 0.3$ & n.d. & $3.5 \pm 0.1$ & $1.9 \pm 0.1$ \\
\hline
\end{tabular}

n.d. $=$ not determined.

${ }^{\mathrm{a}} \mathrm{IC}_{50}=$ compound concentration required to inhibit tumor cell proliferation by $50 \%$. Data are expressed as the IC $\mathrm{C}_{50} \pm \mathrm{SD}$ from the dose-response curves of at least three independent experiments.

For the thiophen-2'-yl derivatives $\mathbf{5 e - i}$, the activity of acetylene derivative 5e was inferior to that of the partially reduced (Z)-ethylene analogue $\mathbf{5 i}$ only against L1210 and Molt4 cells.

In the series of isomeric thiophen-3'-yl derivatives $\mathbf{5 g}, \mathbf{5 j}$, and 5o, compound $\mathbf{5 g}$, with a rigid ethynyl spacer between the $\mathrm{C}-5$ position of the 2-amino-3-(3', $4^{\prime}, 5^{\prime}$-trimethoxybenzoyl)-thiophene skeleton and the thiophen-3'-yl moiety, was more potent as an antiproliferative agent than the corresponding ethenyl derivative $\mathbf{5 j}$ and the ethyl group (analogue 5o) led to a further reduction in activity.

To investigate whether the antiproliferative activities of these compounds were related to an interaction with tubulin, we examined the effects of the more active compounds $\mathbf{5 e - i}$ on the polymerization of purified tubulin, ${ }^{18}$ in comparison with the potent antimitotic compounds $\mathbf{4 d}$ and CA-4 (Table 2). The same compounds were also examined for inhibitory effects on the binding of $\left[{ }^{3} \mathrm{H}\right]$ colchicine to tubulin. ${ }^{19}$

Compounds 5e-i all strongly inhibited tubulin assembly, and compounds $\mathbf{5 f}$ and $\mathbf{5 h}$ seemed to be even more active than the reference compound CA-4. $5 \mathbf{h}$ was found to be the most active $\left(\mathrm{IC}_{50}=0.62 \mu \mathrm{M}\right)$ in the in vitro tubulin polymerization assay, having almost twice the potency of CA-4. In comparison with $\mathbf{4 d}$, compound $\mathbf{5 h}$ was three times as potent as an inhibitor of tubulin assembly, but it was much less active as an antiproliferative agent.

Table 2

Inhibition of tubulin polymerization and colchicine binding by compounds $\mathbf{5 e - i}$, $\mathbf{4 d}$ and $\mathrm{CA}-4$

\begin{tabular}{lcll}
\hline Compound & \multicolumn{2}{c}{ Tubulin assembly } \\
& $\mathrm{IC}_{50} \pm \mathrm{S} . \mathrm{D}(\mu \mathrm{M})$ & \multicolumn{2}{c}{ Colchicine binding $\% \pm$ S.D } \\
\cline { 3 - 4 } & $1.0 \pm 0.1$ & $5 \mu \mathrm{M}$ drug & $1 \mu \mathrm{M}$ drug \\
\hline $\mathbf{5 e}$ & $0.84 \pm 0.1$ & $81 \pm 3$ & n.d. \\
$\mathbf{5 f}$ & $1.0 \pm 0.0$ & $76 \pm 4$ & $47 \pm 4$ \\
$\mathbf{5 g}$ & $0.62 \pm 0.1$ & $90 \pm 2$ & $40 \pm 2$ \\
$\mathbf{5 h}$ & $1.2 \pm 0.1$ & $73 \pm 3$ & $60 \pm 4$ \\
$\mathbf{5 i}$ & $1.9 \pm 0.1$ & n.d. & n.d. \\
$\mathbf{4 d}$ & $1.0 \pm 0.2$ & $99 \pm 0.3$ & $60 \pm 5$ \\
CA-4 (1) & & & $90 \pm 3$ \\
\hline
\end{tabular}

n.d. $=$ not determined.

a Inhibition of tubulin polymerization. Tubulin was at $10 \mu \mathrm{M}$.

b Inhibition of $\left[{ }^{3} \mathrm{H}\right]$ colchicine binding. Tubulin and colchicine were at 1 and $5 \mu \mathrm{M}$ concentration, respectively.
The order of inhibitory action on tubulin assembly was $\mathbf{5 h}>\mathbf{5 f}>$ $\mathbf{5 e}=\mathbf{5} \mathbf{g}=$ CA4 $>\mathbf{5 i}>\mathbf{4 d}$, which was not consistent with the results of the antiproliferative assays. (5g had the greatest antiproliferative activity, although the differences between the most active compounds in the new series were not great). The reduced antiproliferative activities of $\mathbf{5 h}$ and $\mathbf{5 f}$ as compared with $\mathbf{4 d}$ may result from poor permeability into cells, poor solubility in the tissue culture medium or any other mechanism limiting the accessibility of these molecules to cellular tubulin. Nevertheless, we could not exclude the possibility that 4d may affect other molecular targets in addition to microtubules resulting in the enhanced antiproliferative activity.

In the colchicine binding studies, compounds $5 \mathbf{e}-\mathbf{i}$ potently inhibited the binding of $\left[{ }^{3} \mathrm{H}\right]$ colchicine to tubulin, since $70-90 \%$ inhibition occurred with these agents and colchicine both at $5 \mu \mathrm{M}$. None, however, was quite as potent as CA-4, which in these experiments inhibited colchicine binding by $99 \%$. CA-4 proved also to be somewhat more potent than compound $\mathbf{5 h}$, which was the most potent of the new agents, but otherwise the order of activity in the two tubulin-based assays was identical.

The results are consistent with the conclusion that the antiproliferative activity of these compounds derives from an interaction with the colchicine site of tubulin and interference with microtubule assembly.

To further support this observation, we have performed a series of molecular docking simulation using a procedure reported previously. ${ }^{20}$ Interestingly, the ethynyl analogues $\mathbf{5 f - h}$ showed some peculiar features in their binding mode (Fig. 1). The trimethoxyphenyl group is placed in a similar position as the corresponding ring of the co-crystallized DAMA-colchicine, and the amino group formed a hydrogen bond with Thr179. At the same time, the ethynyl side chain reaches a small hydrophobic cleft formed by Ala354 and Leu248, outside the colchicine binging pocket. Interestingly, the methyl group on the amino-thiophene ring of $\mathbf{5 h}$ is also in contact with Leu248, and this interaction could explain the increased antitubulin activity of $\mathbf{5 h}$ versus $\mathbf{5 g}$, which lacks this substituent. These results are in accord with the experimental data.

Because molecules exhibiting effects on tubulin assembly should cause alteration of cell cycle parameters with preferential $\mathrm{G}_{2}-\mathrm{M}$ blockade, flow cytometry analysis was performed to deter- 


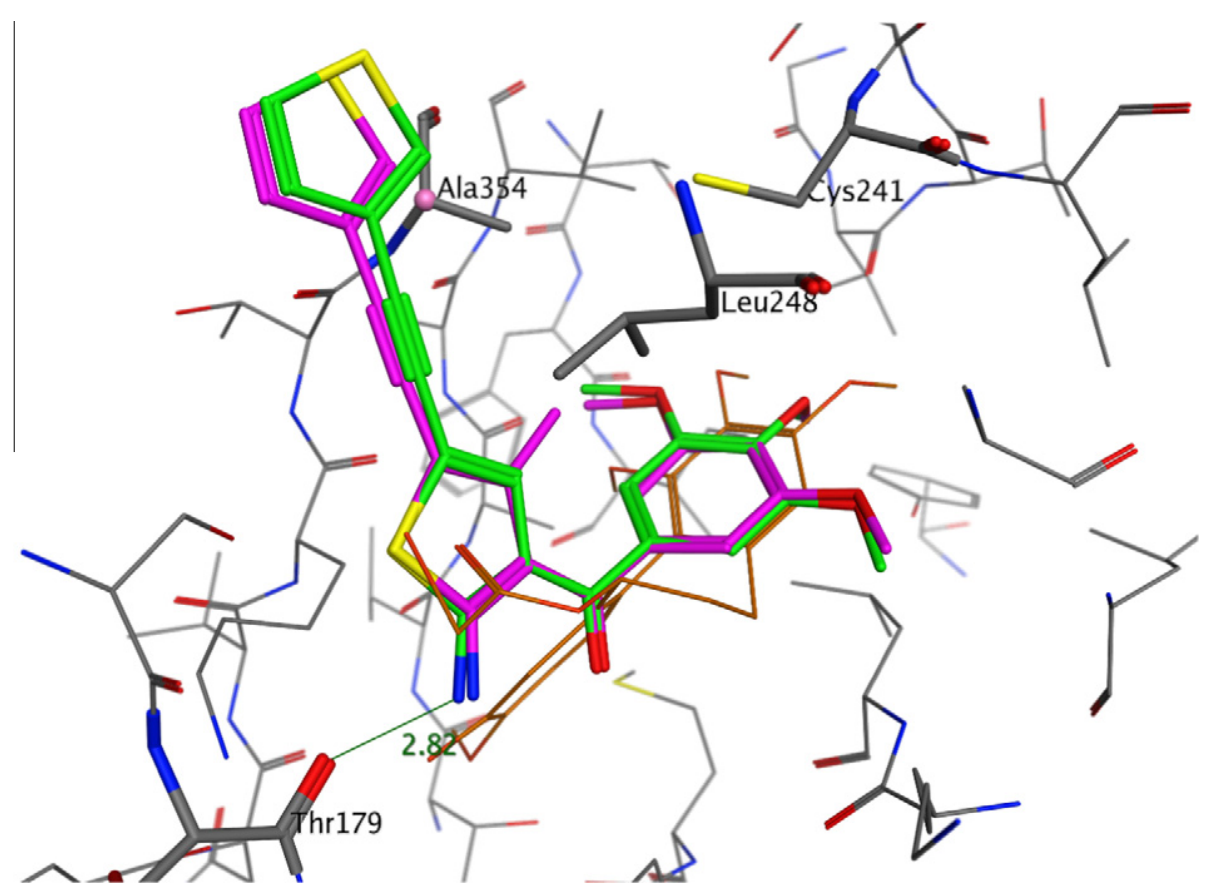

Figure 1. Proposed binding mode of $\mathbf{5 g}$ (in green) and $\mathbf{5 h}$ (in purple). DAMA-colchicine is represented in orange.

Table 3

Effects of compounds $\mathbf{5 e - i}$ on K562 cell cycle progression

\begin{tabular}{lccccc}
\hline \multirow{2}{*}{ Compound } & $\mathrm{IC}_{100}{ }^{\mathrm{a}}(\mathrm{nM})$ & \multicolumn{4}{c}{ Cell cycle distribution (\%) } \\
\cline { 3 - 6 } & & ${\mathrm{Sub}-\mathrm{G}_{1}{ }^{\mathrm{b}}}$ & $\mathrm{G}_{0} \mathrm{G}_{1}$ & $\mathrm{~S}$ & $\mathrm{G}_{2} / \mathrm{M}$ \\
\hline Control & & 2.2 & 43.40 & 40.30 & 16.3 \\
$\mathbf{5 e}$ & $800 \pm 12$ & 16.9 & 22.8 & 25.0 & 52.3 \\
$\mathbf{5 f}$ & $500 \pm 10$ & 6.00 & 3.72 & 13.8 & 82.5 \\
$\mathbf{5 g}$ & $600 \pm 14$ & 15.3 & 21.9 & 40.1 & 38.0 \\
$\mathbf{5 h}$ & $900 \pm 18$ & 16.4 & 25.4 & 25.6 & 49.0 \\
$\mathbf{5 i}$ & $500 \pm 15$ & 16.6 & 21.0 & 41.2 & 37.9 \\
\hline
\end{tabular}

a Compound concentration required to inhibit tumor cell proliferation by $100 \%$. Data are expressed as the mean \pm SD from the dose-response curves of at least three independent experiments.

b Percentage of the cell population with hypodiploid DNA content peak (apoptotic cells).

mine the effect of compounds $\mathbf{5 e - i}$ on K562 (human chronic myelogenous leukemia) cells. The K562 cell line was used because of its rapid proliferation and high sensitivity to standard anticancer agents and in order to determine whether these compounds had activity against human transformed cells. ${ }^{21}$ Cells were cultured for $24 \mathrm{~h}$ in the presence of each compound at the concentration able to inhibit $100 \%$ cell growth $\left(\mathrm{IC}_{100}\right)$ after $24 \mathrm{~h}$, and the results are summarized in Table $3 . \mathrm{IC}_{100}$ was the concentration able to maintain the number of living cells after $24 \mathrm{~h}(T=24 \mathrm{~h})$ at $200,000 / \mathrm{mL}$ which is the number of cells in the control at $T=0$ or the number of cells plated before the treatment. This concentration induced a low percentage of apoptosis (from $6 \%$ for compound $\mathbf{5 f}$ to $16.9 \%$ for compound $\mathbf{5 e}$, as shown by sub- $\mathrm{G}_{1}$ peaks in Table 3 ) but caused important and evident modifications in cell cycle distribution. In fact, all tested compounds caused an increase in the proportion of cells in the $\mathrm{G}_{2}-\mathrm{M}$ peak relative to the untreated control.

In conclusion, a series of analogues with an ethynyl, ethylene or ethyl chain at the C-5 position of 2-amino-3-( $3^{\prime}, 4^{\prime}, 5^{\prime}$-trimethoxybenzoyl)-thiophene core were produced by Sonogashira coupling of the corresponding 5-bromo derivatives with aryl/heteroaryl alkynes, followed by partial or complete reduction of the ethynedyl triple bond. It is clear that the substitution pattern on the 5-position of thiophene ring play an important role for antiproliferative activities, with the thiophen-3'-yl acetylene group as the best substituent of those examined. In the series of thiophen-3'-yl derivatives $\mathbf{5 g}, \mathbf{5 j}$, and $\mathbf{5 0}$, the cell growth inhibition effect increased with increasing rigidity of the linker at the $\mathrm{C}-5$ position of the thiophen-3'-yl group in the 2-amino-3-( $3^{\prime}, 4^{\prime}, 5^{\prime}$-trimethoxybenzoyl)thiophene skeleton. The presence of an acetylene spacer is optimal for activity, while the reduction of acetylene to ethyl decreased antiproliferative activity by $10-100$-fold against all cancer cell lines.

The biological evaluation included extensive antiproliferative studies with five cancer cell lines and examination of some of the most active compounds on tubulin assembly and disruption of the cell cycle. In the latter studies, we observed accumulation of $\mathrm{G}_{2}-\mathrm{M}$ and apoptotic cells, effects expected for compounds that interact with tubulin. 2-Amino-3-( $3^{\prime}, 4^{\prime}, 5^{\prime}$-trimethoxybenzoyl)-5(thiophen-3'-yl ethynyl) thiophene 5g was the most active of the new compounds against cell growth, with $\mathrm{IC}_{50}$ values in the range of $0.1-0.2 \mu \mathrm{M}$. The potency of $\mathbf{5 g}$ as an inhibitor of tubulin assembly was comparable to that of CA-4. When the thiophen-3'-yl group was replaced by a phenyl moiety, activity dropped dramatically. Molecular modeling studies were also performed, and the proposed binding mode for compound $\mathbf{5 h}$ in the colchicine site of tubulin was consistent with the experimental data.

\section{Acknowledgments}

The authors would like to thank Dr. Alberto Casolari and Dr. Erika Marzola for the technical assistance.

\section{Supplementary data}

Supplementary data (detailed biological protocols, synthesis and spectroscopic data for compounds $\mathbf{5 a - 0}$ and $\mathbf{1 0 a}-\mathbf{h}$ ) associated with this article can be found, in the online version, at doi:10.1016/ j.bmcl.2010.11.083. 


\section{References and notes}

1. (a) Walczak, C. E. Curr. Opin. Cell Biol. 2000, 12, 52; (b) Pellegrini, F.; Budman, D R. Cancer Invest. 2005, 23, 264.

2. (a) Amos, L. A. Org. Biomol. Chem. 2004, 2, 2153; (b) Honore, S.; Pasquier, E.; Braguer, D. Cell. Mol. Life Sci. 2005, 62, 3039.

3. (a) Hearn, B. R.; Shaw, S. J.; Myles, D. C. Compr. Med. Chem. II 2007, 7, 81; (b) Kingston, D. G. J. Nat. Prod. 2009, 72, 507.

4. Mahindroo, N.; Liou, J. P.; Chang, J. Y.; Hsieh, H. P. Expert Opin. Ther. Patents 2006, 16, 647 .

5. Jordan, M. A.; Wilson, L. Nat. Rev. Cancer 2004, 4, 253.

6. Pettit, G. R.; Singh, S. B.; Hamel, E.; Lin, C. M.; Alberts, D. S.; Garcia-Kendall, D. Experientia 1989, 45, 209.

7. Cushman, M.; Nagarathnam, D.; Gopal, D.; He, H.-M.; Lin, C. M.; Hamel, E. J. Med. Chem. 1992, 35, 2293.

8. Nam, N. H. Curr. Med. Chem. 2003, 10, 1697.

9. Chaudari, A.; Pandeya, S. N.; Kumar, P.; Sharma, P. P.; Gupta, S.; Soni, N.; Verma, K. K.; Bhardwaj, G. Mini-Rev. Med. Chem. 2007, 12, 1186.

10. Lin, C. M.; Ho, H. H.; Pettit, G. R.; Hamel, E. Biochemistry 1989, 28, 6984

11. Attard, G.; Greystoke, A.; Kaye, S.; De Bono, J. Pathol. Biol. 2006, 54, 72.
12. Tron, G. C.; Pirali, T.; Sorba, G.; Pagliai, F.; Busacca, S.; Genazzani, A. A. J. Med. Chem. 2006, 49, 3033.

13. Pettit, G. R.; Toki, B.; Herald, D. L.; Verdier-Pinard, P.; Boyd, M. R.; Hamel, E.; Pettit, R. K. J. Med. Chem. 1998, 41, 1688.

14. Liou, J. P.; Chang, C. W.; Song, J. W.; Yang, Y. N.; Yeh, C. F.; Tseng, H. Y.; Lo, Y. K.; Chang, Y. L.; Chang, C. M.; Hsieh, H. P. J. Med. Chem. 2002, 45, 2566.

15. Romagnoli, R.; Baraldi, P. G.; Pavani, M. G.; Tabrizi, M. A.; Preti, D.; Fruttarolo, F.; Piccagli, L.; Jung, M. K.; Hamel, E.; Borgatti, M.; Gambari, R. J. Med. Chem. 2006, 49, 3906.

16. Gaukroger, K.; Hadfield, J. A.; Lawrence, N. J.; Nlan, S.; McGown, A. T. Org. Biomol. Chem. 2003, 1, 3033.

17. (a) Chincilla, R.; Najera, C. Chem. Rev. 2007, 107, 874; (b) Heravi, M. D.; Sadijadi, S. Tetrahedron 2009, 65, 7761 .

18. Hamel, E. Cell Biochem. Biophys. 2003, 38, 1.

19. Verdier-Pinard, P.; Lai, J.-Y.; Yoo, H.-D.; Yu, J.; Marquez, B.; Nagle, D. G.; Nambu, M.; White, J. D.; Falck, J. R.; Gerwick, W. H.; Day, B. W.; Hamel, E. Mol. Pharmacol. 1998, 53, 62.

20. Romagnoli, R.; Baraldi, P. G.; Sarkar, T.; Carrion, M. D.; Cara, C. L.; Cruz-Lopez, O.; Preti, D.; Tabrizi, M. A.; Tolomeo, M.; Grimaudo, S.; Di Cristina, A.; Zonta, N.; Balzarini, J.; Brancale, A.; Hsieh, H. P.; Hamel, E. J. Med. Chem. 2008, 51, 1464. 21. Lozzio, C. B.; Lozzio, B. B. Blood 1975, 45, 321. 